\title{
Optimalisasi kapasitas usaha melalui penyusunan rencana usaha dan pembentukan paguyuban UMKM dalam rangka mewujudkan Desa Rejowinangun menjadi kawasan wisata UMKM Kabupaten Blitar
}

\author{
Achmad Murdiono*, Fadia Zen, Andi Basuki, Siska Krisdiana Nofianti \\ Universitas Negeri Malang, Jl. Semarang No. 5 Malang, Jawa Timur, Indonesia \\ *Penulis korespondensi, Surel: achmad.murdiono.fe@um.ac.id
}

Paper received: 5-7-2021; revised: 23-7-2021; accepted: 30-7-2021

\begin{abstract}
Abstrak
Keberadaan UMKM bagi perekonomian di Indonesia tidak diragukan lagi peranannya. Selain menjadi penopang dalam perekonomian nasional, keberadaan UMKM juga menjadi magnet bagi serapan tenaga kerja di Indonesia. Akan tetapi, jumlah UMKM masih tidak sepadan dengan kontribusi terhadap PDB di Indonesia. Oleh karena itu diperlukan upaya dalam penguatan kapasitas usaha UMKM dalam rangka memperkuat peranan UMKM bagi perekonomian di Indonesia. Kegiatan ini bertujuan untuk optimalisasi kapasitas usaha melalui kegiatan penyusunan rencana usaha dan pembentukan paguyuban UMKM. Kegiatan ini dilaksanakan di Desa Rejowinangun Kabupaten Blitar. Pemilihan Desa Rejowinangun dikarenakan desa ini memiliki potensi pengembangan UMKM yang sangat besar dengan keberadaan 83 pelaku UMKM dari 6 jenis usaha. Hasil kegiatan ini adalah tersusunya konsep rencana usaha dari bidang manajemen keuangan, pemasaran produksi dan sumber daya manusia. Selain ini melalui kegiatan ini kelompok UMKM desa Rejowinangun membentuk paguyuban UMKM yang berhasil bersinergi pemerintah desa dan Badan Usaha Milik Desa (BUMDES). Melalui kegiatan ini diharapkan mampu memperkuat peranan UMKM desa Rejowinangun dalam rangka mewujudkan Desa Rejowinangun sebagai desa wisata UMKM di Indonesia.
\end{abstract}

Kata kunci: kapasitas usaha; rencana usaha; paguyuban UMKM

\section{Pendahuluan}

Indonesia dikenal sebagai negara dengan jumlah usaha skala mikro yang sangat besar. Tercatat pada tahun 2019 jumlah UMKM di Indonesia mencapai 48.528 juta atau $98.9 \%$ dari seluruh usaha yang eksis di perekonomian nasional. Selain dari sisi kuantitas, kualitas UMKM juga sudah teruji sebagai penopang ekonomi nasional. Tedjasuksmana (2014) menyatakan bahwa keberadaan UMKM sebagai penopang ekonomi pada masa krisis dan pasca krisis sudah sangat teruji. Selain itu, sektor UMKM juga memberikan sumbangsih yang besar terhadap serapan tenaga kerja di Indonesia (Wijanarko \& Susila, 2016). Meskipun demikian, keberadaan UMKM tidak terlepas dari permasalahan, khususnya permasalahan dalam perluasan usaha. Sehingga kontribusi UMKM terhadap PDB nasional masih lebih kecil dibandingkan dengan usaha skala besar (Kuncoro, 1997). Oleh karena itu, dalam rangka meningkatkan peran UMKM dalam perekonomian nasional diperlukan sebuah pemberdayaan dalam upaya meningkatkan kapasitas usaha UMKM di Indonesia (Irawan, 2020).

Kegiatan pemberdayaan adalah upaya yang membangun daya masyarakat dengan mendorong, memotivasi dan membangkitkan kesadaran akan potensi yang dimiliki serta berupaya untuk mengembangkannya Ginandjar (1996). Mardikato (2015) menyatakan pemberdayaan diartikan sebagai upaya untuk memberikan daya (empowerment) atau penguatan (strengthening) kepada masyarakat. Roosdhani dkk, (2012) dan Hafsah (2004) 
menyatakan bahwa salah satu upaya dalam pemberdayaan UMKM adalah melalui kegiatan pelatihan dan pendampingan. Notoatmodjo (2003) Pendidikan dan pelatihan adalah merupakan upaya untuk mengembangkan sumber daya manusia, terutama untuk mengembangkan intelektual dan kepribadian manusia. Sedangkan Hasibuan (2003) pendidikan dan pelatihan merupakan proses peningkatan keterampilan kerja baik teknis maupun manajerial.

Dalam upaya penguatan kapasitas usaha salah satu pelatihan yang dibutuhkan oleh UMKM adalah penyusunan rencana usaha. Melalui kegiatan penyusunan rencana usaha, UMKM akan memiliki langkah-langkah deskripsi yang jelas dan arah usaha yang jelas sehingga tujuan yang ingin dilakukan dapat tercapai (Sulasih, 2014). Farida et al., (2019) menyatakan bahwa perencanaan bisnis sendiri berarti alat yang dapat digunakan oleh UMKM untuk memberikan keputusan atau kebijakan. Dalam penyusunan rencana usaha harus mengintegrasikan proses pemasaran, produksi, pengembangan usaha, penjualan, transparansi keuangan, sumber daya manusia serta pembelian, pengadaan dan penyediaan peralatan yang dibutuhkan dalam kegiatan usaha (Supriyanto, 2009).

Salah satu kabupaten di provinsi Jawa Timur yang memiliki potensi UMKM adalah kabupaten Blitar. Kabupaten Blitar memiliki sentra UMKM yang berada di desa Rejowinangun, kecamatan Kademangan. Jumlah pelaku usaha di desa Rejowinangun sebanyak 83 UMKM yang terdiri dari 6 jenis usaha. Oleh karena itu tidak heran desa Rejowinangun dikenal sebagai desa UMKM. Akan tetapi, UMKM Desa Rejowinangun juga memiliki beberapa permasalahan. Permasalahan utama yang dihadapi oleh pelaku UMKM adalah promosi produk UMKM dalam skala regional jawa timur dan nasional. Meskipun memiliki potensi yang besar, akan tetapi produk UMKM lebih banyak dikenal di daerah kabupaten Blitar dan sekitarnya. Permasalahan lainnya adalah banyak produk UMKM yang dibeli oleh tengkulak dengan harga yang rendah dan tanpa label. Berdasarkan potensi dan permasalahan diatas, maka kebutuhan utama dalam peningkatan kapasitas UMKM adalah melalui pelatihan penyusunan rencana usaha dan penguatan kelembagaan melalui pembentukan paguyuban UMKM di desa Rejowinangun.

\section{Metode}

Metode Pelaksanaan kegiatan optimalisasi kapasitas usaha melalui penyusunan rencana usaha dan pembentukan paguyuban UMKM dalam rangka mewujudkan desa rejowinangun menjadi kawasan wisata UMKM Kabupaten Blitar ini adalah sebagai berikut:

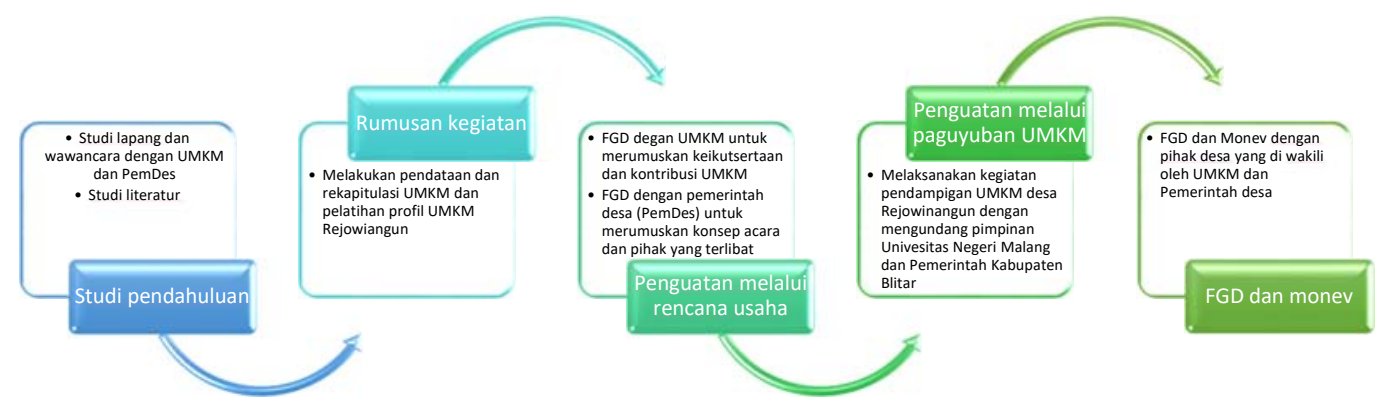

Gambar 1. Rancangan Kegiatan 
Berdasarkan gambar di atas, maka tahap pendahuluan diawali dengan studi literatur kemudian dilanjutkan dengan studi lapang. Studi literatur dilakukan dengan mencari referensi mengenai konsep pendampingan penguatan kapasitas usaha dari UMKM dan membangun kawasan wisata desa UMKM. Dalam rangka memperkuat studi literatur maka dilaksanakan kegiatan studi lapang berupa observasi UMKM di desa Rejowinangun. Oleh karena itu, hal pertama yang dilakukan oleh tim adalah mengidentifikasi kebutuhan akan informasi yang nantinya dijadikan sebagai dasar dalam menyusun rencana kegiatan pelatihan dan pendampingan bagi UMKM.

\section{Hasil dan Pembahasan}

\subsection{Penguatan kapasitas usaha melalui paguyuban UMKM}

Berdasarkan jenis usaha UMKM desa Rejowinangun memiliki beragam potensi usaha. Selain produk geti yang sudah banyak dikenal oleh masyarakat, desa ini juga merupakan sentra dari berbagai macam jenis makanan dan minuman. Berikut ini merupakan rekapitulasi dari jenis usaha dari UMKM desa Rejowinangun:

Tabel 1. Sebaran UMKM desa Rejowinangun

\begin{tabular}{|c|c|}
\hline Jenis Produk & Jumlah \\
\hline Jenang & 23 Orang \\
\hline Kerupuk & 12 Orang \\
\hline Tahu & 08 Orang \\
\hline Dodol & 06 Orang \\
\hline Opak dan & 26 Orang \\
\hline Susu & 08 Orang \\
\hline Jumlah total rumah tangga petani & 83 Orang \\
\hline
\end{tabular}

Berdasarkan potensi di atas, maka data tersebut merupakan bahawa awal dalam menginisiasi pembentukan paguyuban UMKM Desa Rejowinangun. Selain diinisiasi oleh Tim Pelaksanaan kegiatan dari UM, pembentukan paguyuban juga difasilitasi pemerintah desa Rejowinangun. Strategi ini dilakukan oleh tim pelaksana untuk memudahkan menjalin komunikasi dengan para UMKM. Melalui pemerintah desa pihak pelaksana kegiatan mengundang perwakilan UMKM untuk menginisiasi pembentukan paguyuban.

Pengembangan paguyuban UMKM dapat didasarkan pada kerangka hubungan antar dimensi yang secara langsung berpengaruh terhadap aktivitas UMKM yang dinyatakan pada gambar berikut ini:

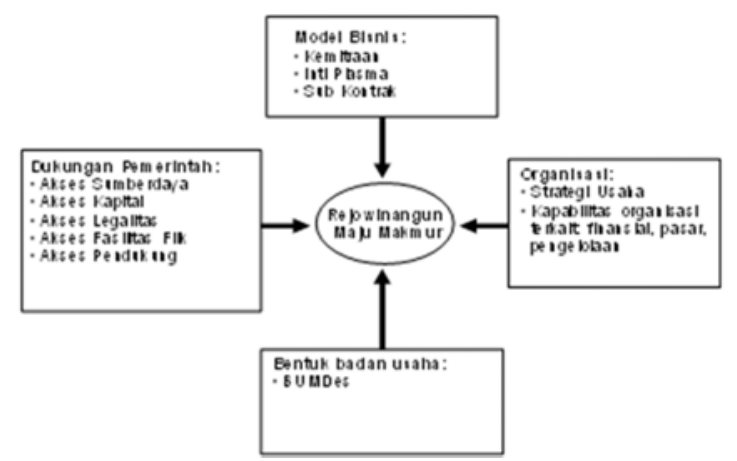

Gambar 2. Dimensi Pengembangan 
Berdasarkan gambar tersebut, terdapat dimensi-dimensi yang relevan sebagai bahan kajian terkait dengan usaha untuk melakukan pengembangan paguyuban UMKM. Model pengembangan bisnis mengungkap beberapa strategi bisnis yang dapat ditempuh adalah dengan cara menetapkan strategi seperti: penciptaan keunggulan bersaing (competitive advantage), penciptaan nilai tambah (adding value), pemilihan pasar yang tepat secara massa atau relung pasar (mass or niche market), strategi berbasis pada biaya (cost-based strategies), dan strategi yang berbasis pada pasar (market-based strategies).

\subsection{Penguatan kapasitas usaha melalui rencana usaha paguyuban UMKM}

Pada umumnya dengan melihat produk UMKM di Desa Rejowinangun banyak dari produknya merupakan produk seasonal yang banyak dinikmati pada momen-momen tertentu seperti idul fitri seperti jenang, geti, dodol, opak. Sedangkan untuk produk yang lain seperti tahu merupakan kebutuhan pokok harian masyarakat sekitar, dan keripik serta susu kambing etawa merupakan jajanan yang tidak dikonsumsi setiap hari. Perbedaan karakteristik dan cara konsumsi produk mempengaruhi penjualan dan pemasaran dari para pelaku UMKM disana.

Oleh karena itu diperlukan sebuah perencanaan usaha yang mampu memaksimalkan usaha dengan karakteristik usaha seperti di atas. Perencanaan usaha pada paguyuban UMKM desa Rejowinangun tidak terlepas dari konsep bisnis digambarkan sebagai berikut.

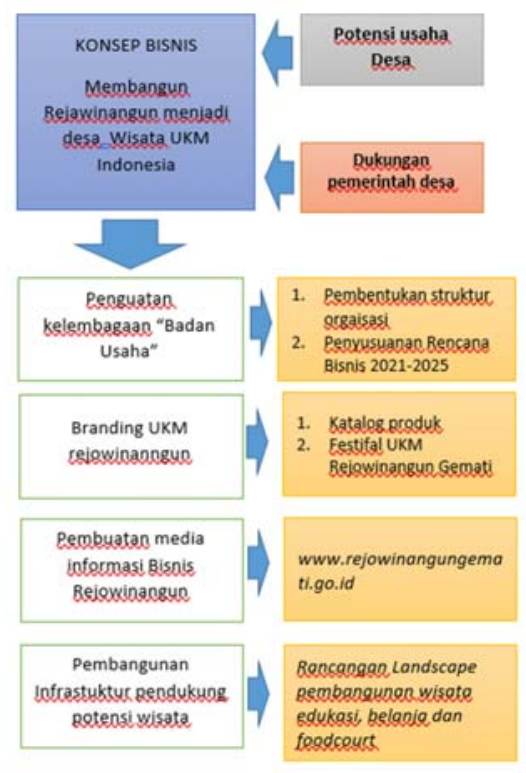

Gambar 3. Konsep bisnis paguyuban UMKM rejowinangun

Berdasarkan gambar di atas, maka konsep bisnis yang dikebangkan meliputi: (1) Penguatan kelembagaan paguyuban UMKM. (2) Branding UMKM melalui penyusunan katalog produk UMKM dan pelaksanaan festival UMKM. (3) Pembuatan media informasi bisnis. (4) Pembangunan infrastruktur pendukung desa wisata Rejowinangun

Pada bagian selanjutnya akan dideskripsikan mengenai rencana usaha berdasarkan bidang manajemen pemasaran, keuangan, operasional dan Sumber Daya Manusia. 


\subsubsection{Manajemen pemasaran}

Pada umumnya produk UMKM di Desa Rejowinangun mayoritas produknya merupakan produk seasonal yang banyak dinikmati pada momen-momen tertentu seperti idul fitri seperti jenang, geti, dodol, opak. Sedangkan untuk produk yang lain seperti tahu merupakan kebutuhan pokok harian masyarakat sekitar, dan keripik serta susu kambing etawa merupakan jajanan yang tidak dikonsumsi setiap hari. Perbedaan karakteristik dan cara konsumsi produk mempengaruhi penjualan dan pemasaran dari para pelaku UMKM disana.

Produk Jenang, geti, dodol, opak, susu kambing etawa, dan keripik banyak dipasarkan di toko-toko, tempat wisata dan menerima pesanan langsung kepada para pengusahanya sedangkan untuk tahu langsung memiliki pelanggan tetap yaitu reseller tahu dan masyarakat yang biasa membeli untuk dikonsumsi sendiri. Sejauh ini pemasaran masih dilakukan dengan tradisional yaitu menjual langsung kepada konsumen tanpa perantara internet atau perangkat digital apapun.

\subsubsection{Manajemen keuangan}

Manajemen keuangan merupakan suatu proses dalam pengaturan aktivitas atau kegiatan keuangan dalam suatu organisasi dimana di dalamnya termasuk kegiatan perencanaan, analisis dan pengendalian terhadap kegiatan keuangan. Secara normatif tujuan keputusan keuangan perusahaan adalah memaksimalkan nilai perusahaan. Tujuan ini identik dengan meminimalkan biaya modal yang harus dikeluarkan oleh perusahaan

Dalam memperoleh sumber pendanaan UMKM Desa Rejowinangun banyak mengandalkan modal sendiri semampunya, apabila pesanan atau permintaan pasar melebihi kemampuan modal sendiri, mereka mengajukan pendanaan ke Bank-Bank. Tidak ada cara khusus dalam mengelola keuangan, bahkan $80 \%$ para pelaku UMKM masih mencampurkan uang usaha mereka dengan uang pribadi mereka dan hanya membuat catatan penerimaan dari penjualan, sehingga tidak dapat diketahui berapa jumlah keuntungan mereka.

Untuk mengefektifkan berbagai macam fungsi dalam manajemen pengelolaan keuangan bisnis, terdapat tugas administrasi yang sebaiknya dilaksanakan oleh para pelaku UMKM. Ketertiban pencatatan administrasi juga sangat bermanfaat sebagai salah satu alat perencanaan pengembangan bisnis

\subsubsection{Manajemen produksi}

Dalam bidang produksi pengusaha-pengusaha besar di sana sudah memiliki alat-alat produksi lebih dari satu dan untuk produksi partai besar, namun lagi-lagi alat produksi tersebut hanya dapat dioptimalkan jika permintaan tinggi dan musim-musim tertentu seperti idul fitri saja, pada hari-hari biasa hanya tahu yang alat produksi beroperasi secara optimal. Mereka pun juga rata-rata telah memiliki supplier atau pemasok bahan baku yang murah sehingga dapat menekan harga pokok produksi, namun lagi-lagi hal itu tidak dapat dioptimalkan jika permintaan tidak optimal. 


\subsubsection{Manajemen Sumber Daya Manusia}

Sumber Daya Manusia (SDM) adalah individu produktif yang bekerja sebagai penggerak suatu organisasi, baik itu di dalam institusi maupun perusahaan yang memiliki fungsi sebagai aset sehingga harus dilatih dan dikembangkan kemampuannya. Dalam sebuah perusahaan, manajemen sumber daya manusia adalah salah satu fungsi yang fokus pada kegiatan rekrutmen, pengelolaan, dan pengarahan karyawan. Pada hakikatnya, SDM terdiri dari daya pikir dan daya fisik setiap manusia, dengan kata lain, terdiri dari jasmani dan rohani

Di bidang sumber daya manusia rata-rata UMKM di Desa Rejowinangun memiliki pegawai 3-8 orang dengan pegawai yang berasal dari masyarakat sekitar atau tetangga. Jumlah pegawainya pun tidak pasti, namun disesuaikan jumlah produksi apabila permintaannya tinggi maka pegawainya semua akan dipanggil namun jika permintaan sedikit maka hanya akan 1-3 orang saja yang dipanggil. Selain itu, pegawai-pegawai di UMKM Desa Rejowinangun menggunakan sistem upah yang didasarkan atas produk yang dihasilkan atau lama jam mereka bekerja. Semua hal tersebut dilakukan untuk menghemat biaya produksi dari UMKM Desa Rejowinangun.

\section{Simpulan}

Berdasarkan hasil dan pembahasan di atas, maka dapat kesimpulan dalam kegiatan ini adalah: (1) Pembentukan paguyuban UMKM merupakan cara yang efektif dan efisien dalam memperkuat kapasitas usaha (keuangan, pemasaran dan produksi) bagi UMKM desa Rejowinangun. (2) Pendampingan dalam penyusunan rencana usaha kepada pelaku UMKM di desa Rejowinangun mampu memperkuat kemampuan manajerial pelaku dalam meningkatkan pengetahuan dan kapasitas dalam berwirausaha

Melalui pembahasan dan berdasarkan temuan-temuan permasalahan UMKM di lapangan, maka berikut ini merupakan saran yang dapat dilakukan pada kegiatan selanjutnya: (1) Melibatkan peran dari Dinas Koperasi dan UMKM Kabupaten Blitar dalam rangka penguatan paguyuban UMKM di Rejowinangun. (2) Penguatan kapasitas manajerial pelaku usaha khususnya dalam hal pengelolaan keuangan dan pemanfaatan media pemasaran online sebagai sarana dalam melakukan ekspansi pasar. (3) Melakukan kegiatan festival UMKM sebagai sarana dalam mengenalkan lebih luas potensi desa Rejowinangun sebagai desa wisata UMKM di Indonesia

\section{Daftar Rujukan}

Farida, I., Aryanto, A., Sunandar, S., Hetika, H., \& Krisdiyawati, K. (2019). IbM Pelatihan Business Plan Pada Umkm Kota Tegal. Jurnal Abdimas PHB: Jurnal Pengabdian Masyarakat Progresif Humanis Brainstorming, 2(2), 64-68. https://doi.org/10.30591/japhb.v2i2.1384

Hafsah, M. J. (2004). Upaya pengembangan usaha kecil dan menengah (UKM). Infokop Nomor, 25, 40-44. Diakses pada tanggal 3 April 2013 pukul 22.15 WIB dari www.smecda.com.

Hasibuan, M. (2003). Manajemen Sumber Daya Manusia, Jakarta: PT.Bumi Aksara

Irawan, P. L. T., \& Prilianti, K. R. (2020). Pemberdayaan Usaha Kecil Menengah (UKM) Melalui Implementasi ECommerce di Kelurahan Tlogomas. Jurnal Solma, 9(1), 33-44.

Kartasasmita, G. (1996). Pembangunan Untuk Rakyat (Memadukan Pertumbuhan Dan Pemerataan) Jakarta: PT. Pustaka SIDESINDO.

Kuncoro, Mudrajad dan PT Asana Wirasta Setia. (1997). Pengembangan Pola Pembinaan Usaha Kecil dan Masyarakat di Sekitar Objek dan Kawasan Pariwisata.PT Asana Wirasta Setia dan Deparpostel. Yogyakarta 
Jurnal Ekonomi, Bisnis dan Pendidikan, 1(7), 2021, 625-631

Mardikanto Totok dan Soebiato Poerwoko. (2015). Pemberdayaan Masyarakat dalam Perspektif Kebijakan Publik, Cet. Ke-3. Bandung: Alfabeta

Notoatmodjo, S. (2003). Pendidikan dan Perilaku Kesehatan, Rineka Cipta. Jakarta, halaman, 114-131.

Roosdhani, M. R., Wibowo, P. A., \& Widiastuti, A. (2012). Analisis tingkat penggunaan teknologi informasi dan komunikasi pada usaha kecil menengah di Kab. Jepara. Jurnal Dinamika Ekonomi \& Bisnis, 9(2).

Sulasih, S. (2014). Business Plan Pengembangan Lembaga dan Usaha Koperasi Sektor Riil dalam Rangka Revitalisasi Koperasi Nira Satria Kabupaten Banyumas. JBIMA (Jurnal Bisnis dan Manajemen), 2(1), 2029.

Supriyanto, S. (2009). Business Plan sebagai Langkah Awal Memulai Usaha. None, 6(1), 17216.

Tedjasuksmana, B. (2014). Potret UMKM Indonesia menghadapi masyarakat ekonomi ASEAN 2015. In The 7th NCFB and Doctoral Colloquium (pp. 189-202).

Wijanarko, A., \& Susila, I. (2016). Faktor Kunci Keberhasilan UMKM Kreatif. 